\title{
The Difficulties of Socio-professional Reintegration of Patients Suffering from Chronic Psychiatric Affections in Lomé
}

\section{Komi Dzidzonu Nemi ${ }^{1 *}$, Kokou Dodzi Mawulolo Dogbe ${ }^{2}$, Essohanam Tambourou $^{1}$, Mohaman Awalou Djibril ${ }^{1}$ and Kolou Simliwa Dassa ${ }^{2}$}

${ }^{1}$ Department of Internal Medicine, Sylvanus Olympio University Hospital, University of Lomé, Togo

${ }^{2}$ University Clinic of Psychiatry and Medical Psychology, Campus University Hospital, University of Lomé, Togo

*Corresponding Author: Komi Dzidzonu Nemi, Department of Internal Medicine, Sylvanus Olympio University Hospital, University of Lomé, Togo.

DOI: $10.31080 /$ ASMS.2020.04.0686
Received: May 21, 2020

Published: July 16, 2020

(C) All rights are reserved by

Komi Dzidzonu Nemi., et al.

\begin{abstract}
The aim of this study was to describe the difficulties of socio-professional reintegration of patients suffering from chronic mental disorders in Lomé. This is a transversal and descriptive study conducted from $1^{\text {st }}$ February to 31st April 2018 concerning patients with chronic mental disorders but stabilized and monitored by the Psychiatry service of the Campus University Hospital of Lomé. Fifty-one (51) stabilized patients were involved. The social and family reintegration was almost total $(\mathrm{N}=50)$. Professional reintegration was not effective in 37 patients (72.5\%). The sex ratio (M/F) was 0.94 . The mean age was $40.7+$ /- 10 years (range 15 and 59 years). The majority (46\%) were single. Psychoses represented $62.16 \%(\mathrm{~N}=23)$ of the diagnoses retained, followed by severe depression ( $\mathrm{N}=11 ; 29.72 \%)$ and mania $(\mathrm{N}=3 ; 8.10 \%)$. Neuroleptics were used in $81 \%$ and antidepressants in $46 \%$ of cases. Before chronic mental disorders and their management, $64.8 \%(\mathrm{~N}=24)$ of patients were in the private sector. The reasons for the nonresumption of activity according to the patients were: the side effects of psychotropic drugs $(\mathrm{N}=16 ; 43.2 \%)$, the lack of motivation $(\mathrm{N}=15 ; 40.5 \%)$, the dismissal $(\mathrm{N}=4 ; 10.8 \%)$ and social stigma $(\mathrm{N}=2 ; 5.4 \%)$. The obstacles to professional reintegration according to the accompanying persons were: non-compliance with customary laws $(\mathrm{N}=11)$, possession by the spirits $(\mathrm{N}=7)$, the curse $(\mathrm{N}=$ 5) and enchantment $(\mathrm{N}=5)$. The difficulties of professional reintegration of patients suffering from chronic psychiatric affections are topical in our country. A refocused study including the community level and supporting the daily experience of these patients would be desirable to complete our work.
\end{abstract}

Keywords: Difficulties; Reintegration; Professional; Psychiatric Patients - Lomé (TOGO)

\section{Introduction}

Chronic mental disorders are nowadays a real public health problem worldwide [1]. In low- income countries, they are responsible for $12 \%$ of the overall disease burden among adults aged 15 to 44 [2]. Our country Togo is not spared [3,4]. These disorders affect the socio-professional life of the individual and those around him [5]. But most of them can be successfully treated through pharmacologic advances related in particular to novel antipsychotics, more respectful of cognitive performance than previous treatments, provide better than before to consider a resumption of activity [6]. However, this resumption of activity is sometimes subject to obstacles [6]. 


\section{Aim of the Study}

This work aims to describe the difficulties in the socio-professional reintegration process of patients with chronic mental disorders cared for in a psychiatric environment in Lomé.

\section{Patients and Methods}

It was a cross-sectional study for descriptive purposes which took place at the Psychiatry and Medical Psychology Clinic of the Campus University Hospital in Lomé. It spread over three months from $1^{\text {st }}$ February to 31 April 2018. It covered every patient stabilized, gender (male or female) regardless of age, received in psychiatric consultation and monitoring for a chronic mental disorder. Any significant clinical disturbance in cognition, in the regulation of emotions, or in the behavior of a person who reflects a dysfunction in the psychological process and has been evolving for more than six months, was considered to be a chronic mental disorder. We proceeded to administer questionnaires to patients received in consultation and meeting the inclusion criteria. The interview with the carers was done after that of the patients seen separately. The data were collected on a data collection form after verbal consent from the patient and his companion. The questionnaires were administered in three languages (French and the two main national languages of Togo: Ewé and Kabyè) according to the preference of each respondent. The resource persons and support staff allowed us to assess the qualitative aspect of the questionnaires and thus complete the information provided by stabilized patients. The parameters studied were: epidemiological, clinical, therapeutic data and socio-professional survey. The data was processed by Epi data software.

\section{Results}

\section{Socio-demographic data}

This study involved 51 stabilized patients. Among them, sociofamily reintegration was almost total, but professional integration was not effective in 37 patients, i.e. a rate of $72.5 \%$ of non-professional integration. The sex ratio (M/F) was 0.94 (18 men and 19 women). The mean age was $40.7+/-10$ years with extremes of 15 and 59 years.

Forty-three commas three percent (43.3\%) of the patients were between 30 and 49 years of age (Table 1 ).
Seventeen patients (46\%) were single, 15 patients $(40.5 \%)$ married, 4 patients (10.8\%) widowed and one $(2.7 \%)$ divorced. Twenty-two patients (59\%) lived in rentals and fifteen patients $(41 \%)$ lived in private residences. Seventy point three percent $(\mathrm{N}=$ 26 ) of patients had a secondary education level less than or equal.

\begin{tabular}{|l|c|c|}
\hline Age in year & Number & Percentage (\%) \\
\hline$[16-19]$ & 1 & 2.7 \\
\hline$[20-29]$ & 8 & 21.6 \\
\hline$[30-39]$ & 7 & 19 \\
\hline$[40-49]$ & 9 & 24.3 \\
\hline$[50-59]$ & 12 & 32.4 \\
\hline Total & 37 & 100 \\
\hline
\end{tabular}

Table 1: Distribution of patients by age in years.

\section{Clinical data}

The schizophrenic psychoses accounted for $40.5 \%$ of diagnoses retained followed by severe depression (29.8\%) (Table 2).

\begin{tabular}{|l|c|c|}
\hline & Number & Percentage (\%) \\
\hline Depression & 11 & 29.7 \\
\hline Schizophrenic psychoses & 15 & 40.5 \\
\hline Non-schizophrenic psychoses & 8 & 21.6 \\
\hline Manias & 3 & 8.1 \\
\hline Total & 37 & 100 \\
\hline
\end{tabular}

Table 2: Distribution of patients according to the diagnosis selected.

\section{Therapeutic data}

Neuroleptics were used in $81 \%$ and antidepressants in $46 \%$ of the cases (Table 3).

\begin{tabular}{|l|c|c|}
\hline & Number & Percentage (\%) \\
\hline Neuroleptics & 30 & 81 \\
\hline Antidepressants & 17 & 46 \\
\hline Anxyolytics & 9 & 24.3 \\
\hline Correctors & 13 & 35 \\
\hline Thymoregulators & 9 & 24.3 \\
\hline
\end{tabular}

Table 3: Distribution of patients according to the classes of psychotropic drugs. 
The psychotropic association concerned 35 patients for six different psychotropic associations depending on their diagnoses and clinical conditions. Two patients were on neuroleptic monotherapy (Table 4).

\begin{tabular}{|l|c|c|}
\hline & Number & Percentage (\%) \\
\hline $\begin{array}{l}\text { Neuroleptic/antidepressant/ } \\
\text { corrector }\end{array}$ & 6 & 16.2 \\
\hline Neuroleptic/antidepressant & 4 & 10.8 \\
\hline Neuroleptic/Thymoregulators & 9 & 24.3 \\
\hline Neuroleptic/anxiolytic & 2 & 5.4 \\
\hline Neuroleptic/corrector & 7 & 19 \\
\hline Antidepressant/anxiolytic & 7 & 19 \\
\hline Neuroleptic & 2 & 5.4 \\
\hline Total & 37 & 100 \\
\hline
\end{tabular}

Table 4: Distribution of patients according to associations or not of psychotropic drugs.

\section{Social and professional characteristics of patients}

Before chronic mental disorders and their treatment, $64.8 \%$ of patients $(\mathrm{N}=24)$, worked in the private sector, $19 \%(\mathrm{~N}=7)$ were public servants and $16.2 \%(\mathrm{~N}=6)$ learners. Twenty-five patients $(67.6 \%)$ are said to have a good relationship with their families. Thirty-two patients had a conjugal relationship, of which 15 were legally married. Among the 32, seventeen patients (53\%) would have a good relationship with their partners. Seventy-three percent $(\mathrm{N}=27)$ of patients, reported having good relationships with their communities. Five patients $(13.5 \%)$ would be marginalized and five discriminated against. After treatment, socio-family reintegration was effective in 50 patients. The reasons for not resuming activity were: side effects of psychotropic drugs ( $\mathrm{N}=16 ; 43.2 \%)$, lack of motivation $(\mathrm{N}=15 ; 40.5 \%)$, dismissal $(\mathrm{N}=4 ; 10.8 \%)$ and social stigma $(\mathrm{N}=2 ; 5.4 \%)$. The obstacles to socio-professional reintegration according to the carers were: non-compliance with customary laws $(\mathrm{N}=11)$, possession by spirits $(\mathrm{N}=7)$, the curse ( $\mathrm{N}$ $=5)$ and enchantment $(\mathrm{N}=5)$. Nine patients reported no barriers to reintegration.

\section{Discussion}

We recorded a high rate of socio-family reintegration against a low rate of professional reintegration in our study $(27,5 \%)$ thus joining the data of an Ivorian series [7]. The non-professional re- integration equally affected men and women in our series. Variations in the sex ratio were observed for all chronic mental disorders. Indeed, female prevalence has been reported in some series $[4,8,10]$. On the other hand, the male preponderance was noted by Ihezue., et al. [11] and by Ouedraogo., et al. [12]. However, if chronic mental disorders, like schizophrenia, are generally later and less severe in women, the cumulative incidence rates seem to be the same throughout life $[3,13]$. Our study population was made up of young subjects who were active before their illness. In general, psychiatric disorders are the prerogative of young adults in our country. Effectively, another Togolese series has reported a mean age of 31.5 years [4]. This same observation was made by African $[7,11,12,14]$ and overseas authors $[15,16]$. The prevalence of psychiatric disorders in this social layer could be explained by professional and marital concerns during this critical period of life [4]. Singles predominated in our series confirming data from the literature $[4,16]$. Clinically, psychoses were the majority $(72.1 \%)$ in our study with schizophrenic psychoses as leader followed by depression. In reality, on the nosological level, two pathologies of unequal gravity occupy the first places: depression disorders and psychoses [2]. Their prevalence varies from one country to another. In the Beninese [17], Cameroonian [14], and Madagascan [2] series, depressive disorders rank first followed by psychoses. On the other hand, psychotic disorders predominated in a Burkinabe series and in another Togolese series [4]. The preponderance of psychotic disorders in our country could be explained by their major symptoms including the aggressiveness, the agitation, and the polymorphic delirium that motivate faster psychiatric consultation while depression with its symptoms not disturbing the family environment do not encourage psychiatric consultations [4]. The side effects of psychotropic drugs were, according to the patients, the main reason for not resuming activity in our series. Truly, the side effects induced by the psychotropic drugs are diverse and likely to alter, sometimes seriously, the quality of life [7]. These effects are dominated by extrapyramidal symptoms (akathisia, akinesia, etc.) [18]. Therefore, it is reduced doses of psychotropic drugs that is to say established case by case depending on the symptomatic effect and of the tolerance of the treatment which provide the best skills social of patients [7]. The other reason s of non-resumption of activity evoked by our patients were the lack of motivation for fear of being stigmatized, the dismissal and social stigma. Stigma and discrimination against people with mental illness has existed through the ages and stigma has been classified by the World Health Or- 
ganization (WHO) as "the most important barrier to overcome in the community" [18]. To reduce these practices in our country, specialists in the social sciences, mental health and public health must work together to establish an anti-stigma program. The obstacles to the reintegration according to the carers of our patients was explained by the etiologies of their mental disorders which were of a mystico-religious order. Surely, in African societies and particularly in Togo, mental disorders, especially psychoses often have a supernatural interpretation $[2,4,19,20]$. This directs the patient's family to traditional therapists or prayer centers. To take the example of Senegal, all the patients received in psychiatric institutions are seen by traditional healers either before, during or after hospitalization, and it is often the family who consults the traditional therapist, sometimes even without the patient's knowledge [19]. The role of practitioners of traditional medicine is important as well as that of priests and pastors. It takes a very good collaboration between these practitioners and those of conventional medicine for the benefit of patient's suffering from psychiatric disorders.

\section{Conclusion}

Chronic mental rubles are disabling diseases and are therefore a major public health problem. This study shows a high rate of nonreintegration of stabilized psychiatric patients. The reinsertion difficulties encountered in our patients in particular, the side effects of the drugs, the stigmatizations and the supernatural reasons remain similar to those encountered on our content. Adherence therapy, psychological and religious accompaniments, and reintegrative socio-therapeutic activities remain the royal way to guaranteed socio-professional reintegration. A broader study in the community will allow a more exhaustive assertion of the reintegration difficulties of stabilized patients.

\section{Conflicts of Interest}

None.

\section{Bibliography}

1. Mikolajczak E. "Insertion socioprofessionnelle et Santé Mentale”. L'Essor 71.28 (2015):4-9

2. Andriantseheno LM., et al. "Les troubles psychiatriques à Madagascar: étude clinique de 376 cas répertoriés à Mahajanga". Le Bulletin de la Société de Pathologie Exotique 97.2 (2004) :122-126
3. Dassa KS., et al. "Les troubles psychopathologiques associés à l'abus des substances psychoactives à l'hôpital psychiatrique de Zébé (Togo)". Journal de la Recherche Scientifique de l'Université de Lomé D 10.2 (2008):155-160.

4. Salifou S., et al. "Profil des patients vus en consultation psychiatrique au CHU-Campus de Lomé". Health Sciences and Disease 19.1 (2018): 48-52.

5. Burns T., et al. "The effectiveness of supported employment for people with severe mental illness: a randomised controlled trial". Lancet 370 (2007): 1146-1152.

6. Pachoud B., et al. "La problématique de l'insertion professionnelle des personnes présentant un handicap psychique: les différentes dimensions à prendre en compte". RFAS (2009): 257-277.

7. Yao YP., et al. "Prescription des psychotropes: difficultés et perspectives en Côte d'Ivoire (Afrique de l'Ouest)". L'Information Psychiatrique 85.8 (2009):709-714.

8. Tognidé CM., et al. "Itinéraire thérapeutique des malades mentaux reçus dans le service de psychiatrie du CNHU-HKM de Cotonou (Bénin)”. Le Bénin Médical 45/46 (2010): 32-38.

9. Pilon W., et al. "Caractéristiques des populations au Centre Hospitalier psychiatrique Robert-Giffard: Personnes ayant des incapacités intellectuelles et personnes atteintes de maladie mentale". Sant Ment Quebec 22 (1997): 115-136.

10. Kovess V., et al. "La santé mentale en région Ile-de-France: des données épidémiologiques à la planification". Information Psychiatric 76 (2002): 43-55.

11. Ihezue UH., et al. "Admissions and readmissions into a psychiatric hospital in Nigeria. A study of demographic and clinical correlates". Psychopathy African 25 (1993): 105-114.

12. Ouedraogo A., et al. "Caractéristiques de la population prise en charge au Service de Psychiatrie du CHU Yalgado Ouédraogo de Ouagadougou (Burkina Faso) de 1990 à 2000". L'Encéphale 32.1(2006): 437-443.

13. De Clercq DM., et al. "Les troubles schizophréniques". Univ. De Boeck. 2 (1999): 3-21

14. Ntone-Enyime F., et al. "La Réhabilitation Psychosociale du malade Mental Errant au Cameroun. Analyse d'une activité pilote". Health Science and Disease 17.1 (2016): 1-5. 
15. Chastang F., et al. "Etude épidémiologique des patients et suicidants admis aux urgences psychiatriques d'un hôpital général". Revue d'Epidémiologie et Santé Publique 44.5 (1996): 427-436.

16. Young LT., et al. "Psychiatric Consultation in the Eastern Canadian Arctic: II. Referral Patterns, Diagnoses and Treatment". Canadian Journal of Psychiatry 38.1 (1993): 28-31.

17. Gansou G M., et al. "Psychiatrie itinerante à Cotonou au Benin". Le Bénin Médical 48 (2011): 17-22.

18. Stuart H. "Stigmatisation: Leçons tirées des programmes visant sa diminution”. Santé mentale au Québec 28.1 (2003):54-72

19. Halle A., et al. "Aspects particuliers de la psychiatrie en Afrique: rencontre de deux systèmes de soins". L'information Psychiatrique 71.6 (1995): 530- 536.

20. Dimbu FA., et al. "Prise en charge globale des maladies mentales chez les Suku de Congo-Kinshasa”. ERES Empan 101 (2016): 119-126.

\section{Assets from publication with us}

- Prompt Acknowledgement after receiving the article

- Thorough Double blinded peer review

- Rapid Publication

- Issue of Publication Certificate

- High visibility of your Published work

Website: www.actascientific.com/

Submit Article: www.actascientific.com/submission.php

Email us: editor@actascientific.com

Contact us: +919182824667

Citation: Komi Dzidzonu Nemi., et al. "The Difficulties of Socio-professional Reintegration of Patients Suffering from Chronic Psychiatric Affections in Lomé". Acta Scientific Medical Sciences 4.8 (2020): 26-30. 